\title{
Leishmania (Viannia) braziliensis is the main species causing cutaneous leishmaniasis in the Federal District of Brazil
}

\author{
Santos GM (1), Kückelhaus SA (2), Roselino AM (3), Chaer WK (4), Sampaio RNR (1)
}

(1) Dermatology Service, University Hospital of Brasília, Laboratory of Dermatomycology, School of Medicine, University of Brasília, Brasília, Brazil; (2) Laboratory of Histology and Embryology, Morphology Area, School of Medicine, University of Brasília, Brasília, Brazil; (3) Multiuser Laboratory of Molecular Biology, Department of Internal Medicine, Ribeirão Preto School of Medicine, University of São Paulo (USP), Ribeirão Preto, São Paulo State, Brazil; (4) Higher School of Health Sciences, Federal District Health Department, Brasília, Brazil.

\begin{abstract}
The first autochthonous case of American cutaneous leishmaniasis was reported in the Federal District in 1980, and the species involved in this type of leishmaniasis was unknown. This study aimed to identify the species that causes the disease in the Federal District and to investigate its clinical and epidemiological aspects. Between 2000 and 2007, 71 autochthonous cases of leishmaniasis were reported in the Federal District. Leishmania species were identified by means of direct immunofluorescence reactions using monoclonal antibodies and restriction fragment length polymorphism. The species of 40 (56.33\%) out of 71 samples were identified. Thirty-six (90\%) were identified as Leishmania (Viannia) braziliensis and four (10\%) were identified as Leishmania (Leishmania) amazonensis. In this area, the disease had clinical and epidemiological characteristics similar to those found in other Brazilian regions.
\end{abstract}

Key words: American cutaneous leishmaniasis, Leishmania Viannia braziliensis, Federal District, autochthonous cases.

According to data from the World Health Organization, one person becomes infected with cutaneous leishmaniasis every 20 seconds (1). Brazil has the highest global incidence of American cutaneous leishmaniasis (ACL), and the disease has been spreading throughout its regions since $1980(1,2)$.

The first autochthonous case of ACL in the Federal District (FD) was published in 1980. It was identified in a two-year-old child who lived in the Administrative Region (AR) of Guara and who had never left the Federal District (FD) (3). In the early 1990s, the urban presence of Lutzomyia (Nyssomyia) whitmani (phlebotomine sand flies) was reported in the FD $(4,5)$. Four years later, four cases of ACL were published, and the hypothesis of peridomestic infection was raised. This hypothesis has now been strongly reinforced by several findings (6-8).
The objective of this study was to identify the Leishmania species that cause ACL in the FD and to investigate the clinical and epidemiological aspects of the disease. It is a descriptive study conducted from 2000 to 2007 in the FD, CentralWest Region (CWR) of Brazil. In this period 329 cases were reported to the National Notifiable Diseases Information System (SINAN). Of them, 71 patients met the criterion of having lived in and had never left the FD for more than six months before the diagnosis and 40 of these patients were treated at the University Hospital of Brasilia (HUB) (reference center for the diagnosis and treatment of ACL according to the Brazilian Ministry of Health) and were selected for study.

The criteria used for diagnosis were clinical and epidemiological history and at least two positive or compatible tests (demonstration 
of amastigotes, indirect immunofluorescence, Montenegro skin test).

We used samples of cultures that had been cryopreserved in the Laboratory of Dermatomycology and biopsy imprints on filter paper collected from the lesions to identify the Leishmania species. The techniques used for species identification were PCR-RFLP (restriction fragment length polymorphism), according to a protocol by Medeiros et al. (9), and direct immunofluorescence with monoclonal antibodies, according to Shaw et al. (10).

This study is in compliance with the resolution n. 196/96 of the National Health Council, Brazilian Ministry of Health, on research involving human participants. The Research Ethics Committee of the University of Brasilia also approved the research (005/2005).

The patients came from nine different administrative regions of the FD. The administrative region of São Sebastião presented the greatest number of Individuals $(n=21)$, followed by Planaltina $(n=8)$, Sobradinho $(n=3)$, Gama and Paranoá (each of these AR presented 2 individuals). Brazlândia, Taguatinga, Ceilândia, and Riacho Fundo had one case each.

Thirty-six patients were infected with $L$. (V.) braziliensis and four with $L$. (L.) amazonensis. This result was consistent with the two techniques. Thirty four patients presented a single lesion, while six had multiple lesions. The lesions presented as ulcers in 38 patients, while two patients had papules. The size of the ulcers varied from small in 27 individuals to medium and large in eight and four people, respectively (Table 1).

Thirty-three patients were male and 32 were over 21 years old. Thirty of them lived and worked in cities (Table 2).

The study showed that most patients were from the AR of São Sebastião, which had an outbreak in 2003 and a high incidence of cases in 2006 and 2007 (11). However, these data are not enough to determine that they were infected in that region.

The urban and rural populations of the FD, located in the Central-West Region of Brazil, have increased significantly since the 1960s, when Brasilia, the federal capital, started to be built. This increase was especially due to migratory movements of people from other states of the country to the region and led to deforestation and

Table 1. Clinical data of 40 individuals with autochthonous American cutaneous leishmaniasis in the Federal District, Central-West Region of Brazil

\begin{tabular}{c|c|c|c|c}
\hline $\begin{array}{c}\text { Number of lesions } \\
\mathbf{n}(\%)\end{array}$ & $\begin{array}{c}\text { Isolated } \\
34(85)\end{array}$ & $\begin{array}{c}\text { Multiple } \\
6(15)\end{array}$ & -- & - \\
\hline $\begin{array}{c}\text { Lesion sites } \\
\mathbf{n}(\%)\end{array}$ & Arms & Legs & Arms and legs & Head and thorax \\
\hline $\begin{array}{c}\text { Aspect of lesions } \\
\mathbf{n}(\%)\end{array}$ & Ulcer & Papule & & $1(17)$ \\
\hline $\begin{array}{c}\text { Area of lesions }\left(\mathbf{c m}^{2}\right) \\
\mathbf{n}(\%)\end{array}$ & $38(95)$ & $24(5)$ & - & - \\
\hline
\end{tabular}

Table 2. Epidemiological data of 40 individuals with autochthonous American cutaneous leishmaniasis in the Federal District, Central-West Region of Brazil

\begin{tabular}{c|c|c}
\hline $\begin{array}{c}\text { Gender } \\
\text { n. (\%) }\end{array}$ & $\begin{array}{c}\text { Age (years) } \\
\text { n. (\%) }\end{array}$ & $\begin{array}{c}\text { Place of infection } \\
\text { n. (\%) }\end{array}$ \\
\hline Male & 10 to 20 & City \\
$33(83)$ & $8(20)$ & $30(75)$ \\
\hline Female & 21 or more & City surroundings \\
$7(18)$ & $32(80)$ & $(25)$ \\
\hline
\end{tabular}


environmental changes, which may have caused the vector to change habitat.

This study was the first to identify the Leishmania species in the chain of transmission of the FD. It was found that $L$. (V.) braziliensis is responsible for most cases of the disease. The high frequency of these species corroborates the findings of other endemic regions of Brazil (2). The high frequency of $L$. (V.) braziliensis coincides with the frequent finding of L. whitmani, a sand fly that can transmit this parasite to humans and domestic mammals $(12,13)$. In contrast, the low frequency of $L$. $(L)$. amazonensis could be attributed to the low anthropophilia of its most frequent vector, L. flaviscutelata, which has also been found in the FD.

The individuals with autochthonous ACL predominantly presented small isolated ulcerative lesions on the legs. These findings are similar to those commonly described for this infection (14-17). The predominance of isolated lesions on the legs reflects the area of exposure to the bite of the vector, while bigger ulcerative lesions could be related to a delay in seeking medical assistance.

In conclusion, these findings could improve knowledge about how ACL behaves in the FD of Brazil and help to establish control and prevention measures.

\section{ACKNOWLEDGMENTS}

We would like to thank Edna Ishikawa, Tércio Rodrigues Pereira and Sandra S. R. Souza for their help with species identification and their technical assistance.

\section{COPYRIGHT}

(c) CEVAP 2012

\section{SUBMISSION STATUS}

Received: June 11, 2012.

Accepted: August 2, 2012.

Abstract published online: August 7, 2012.

Full paper published online: August 31, 2012.

\section{CONFLICTS OF INTEREST}

The authors declare no conflicts of interest.

\section{FINANCIAL SOURCE}

The Foundation for Research Support of Federal District (FAP-DF), grant n. 193000332/2007, and the National Council for Research and
Development (CNPq), grant n. 478575/2008-4, provided the financial support to this study.

\section{ETHICS COMMITTEE APPROVAL}

The present study was approved by the Research Ethics Committee of the University of Brasília, Brasília, DF, under registration number $005 / 2005$. Furthermore, it is in compliance with the resolution n. 196/96 of the National Health Council, Brazilian Ministry of Health, on research involving human participants.

\section{CORRESPONDENCE TO}

Raimunda Nonata R. Sampaio, SHIS QI 25, conjunto 2, casa 1, Brasília, Distrito Federal, 71660-220, Brasil. Phone: + 556133671331. Email: raimunda.sampaio@gmail.com.

\section{REFERENCES}

1. World Health Organization [Internet]. Leishmaniasis. [cited 2009 July 10]. Available from: http://www. who.int/tdr/publications/publications/pdf/pr17/ leishmaniasis.pdf.

2. Brasil. Ministério da Saúde. Secretaria de Vigilância em Saúde. Epidemiologia. Manual de vigilância da leishmaniose tegumentar americana. 2th ed. Brasília: Editora do Ministério da Saúde; 2007. p. 15-25.

3. Sampaio RN, Rocha RA, Marsden PD, Cuba CA, Barreto A. Leishmaniose tegumentar americana. Casuística do Hospital Escola da Universidade de Brasília. An Bras Dermatol. 1980;55(2):69-72.

4. Lemos JC, Lima SC, Costa MB, Magalhães MJ. Leishmaniose tegumentar americana: fauna flebotomínica em áreas de transmissão no município de Uberlândia, Minas Gerais, Brasil. Rev C Geog. 2001;2(3):57-73.

5. Missawa NA, Maciel GB, Rodrigues H. Distribuição geográfica de Lutzomyia (Nyssomyia) whitmani (Antunes \& Coutinho 1939) no Estado de Mato Grosso. Rev Soc Bras Med Trop. 2008;41(4):369-73.

6. Sampaio RN, Gonçalves MC, Leite VA, França BV, Santos GM, Carvalho MS, et al. Estudo da transmissão da leishmaniose tegumentar americana no Distrito Federal. Rev Soc Bras Med Trop. 2009;42(6):686-90.

7. Sampaio RN, de Paula CD. Leishmaniose tegumentar americana no Distrito Federal. Rev Soc Bras Med Trop. 1999;32(5):523-8

8. Carvalho MS, Bredt A, Meneguin ER, Oliveira C. Flebotomíneos (Diptera: Psychodidae) em áreas de ocorrência de leishmaniose tegumentar americana no Distrito Federal, Brasil, 2006 a 2008. Epidemiol Serv Saúde. 2010;19(3):227-37.

9. Medeiros AR, Silva WA Jr, Roselino AM. DNA sequencing confirms the involvement of Leishmania (L.) amazonensis in American tegumentary leishmaniasis in the state of São Paulo, Brazil. Clinics. 2008;63(4):451-6. 
10. Shaw JJ, Ishikawa EA, Lainson R. A rapid and sensitive method for the identification of Leishmania with monoclonal antibodies using fluorescein-labelled avidin. Trans R Soc Trop Med Hyg. 1989;83(6):783-4.

11. Brasil. Secretaria do Estado de Saúde do DF. Relatório epidemiológico de agravos de notificação compulsória. Brasília: DIVEP/SVS/SES/DF; 2007. Available from: http://www.saude.df.gov.br/sites/300/373/00000261. pdf.

12. da Costa SM, Cechinel M, Bandeira V, Zannuncio JC, Lainson R, Rangel EF. Lutzomyia (Nyssomyia) whitmani s.l. (Antunes \& Coutinho 1939) (Diptera: Psychodidae: Phlebotominae): geographical distribution and the epidemiology of American cutaneous leishmaniasis in Brazil: mini-review. Mem Inst Oswaldo Cruz 2007;102(2):149-53.

13. Dias-Sversutti AC, Scodro RB, Reinhold-Castro KR, Neitzke HC, Teodoro U. Estudo preliminar da preferência alimentar de Nyssomyia neivai (Pinto) e Nyssomyia whitmani (Antunes \& Coutinho) (Diptera: Psychodidae) em área rural do Paraná. Neotrop Entomol. 2007;36(6):953-9.
14. Reis Lde C, Brito ME, Almeida EL, Félix SM, Medeiros AC, Silva CJ, et al. Clinical, epidemiological and laboratory aspects of patients with American cutaneous leishmaniasis in the State of Pernambuco. Rev Soc Bras Med Trop. 2008;41(5):439-43.

15. Lessa MM, Lessa HA, Castro TW, Oliveira A, Scherifer A, Machado P, et al. Mucosal leishmaniasis: epidemiological and clinical aspects. Braz J Otorhinolaryngol. 2007;73(6):843-7.

16. Name RQ, Sampaio RN, Borges KT, Nogueira LS, Sampaio JH, Tauil PL. Estudo clínico, epidemiológico e terapêutico de 402 pacientes com leishmaniose tegumentar americana atendidos no Hospital Universitário de Brasília, DF Brasil. An Bras Dermatol. 2005;80(3):249-54.

17. Almeida AF, Castro MC, Oliveira AP, Souza MA, Pereira VR. Immunophenotypic characterization of patients with American cutaneous leishmaniasis prior to and after treatment in Pernambuco, Brazil. J Venom Anim Toxins incl Trop Dis. 2011;17(2):230-4. 